\title{
THE INFLUENCE OF CIVIC AND CITIZENSHIP EDUCATION ACHIEVEMENTS ON THE DEVELOPMENT OF STUDENTS' CITIZENSHIP ATTITUDES
}

Andrejs Geske, Ireta Cekse

University of Latvia, Latvia

E-mail: andrejs.geske@lu.Iv, ireta.cekse@lu.Iv

\begin{abstract}
Civic skills, knowledge and attitudes are the elements forming the citizenship concept. How do they suit multicultural societies? What are the mutual links among civic attitudes, knowledge and skills of different ethnic groups? The aim of the research is to establish the model of students' civic competence and to find out factors which explain the influence of civic achievements on civic attitudes. IEA (the International Association for the Evolution of Educational Achievement) ICCS 2009 (the International Civic and Citizenship Studies 2009) are used for the analysis. SEM (Structural Equation Modelling) is used for data processing. The authors used multi-modelling to compare Latvian and Estonian majority and minority sample groups. The results indicate that the level of civic knowledge and skills influences civic attitudes of Estonian and Latvian students. Students with a higher level of civic knowledge and skills have a more pronounced sense of global belonging and ability to adjust and live a multicultural society. The civic knowledge of Estonian students with the Estonian language of instruction influences most essentially the civic attitudes and a sense of belonging to Europe. Latvian students with the Russian language of instruction have the least influence on the mentioned factors.
\end{abstract}

Key words: civic and citizenship education, Estonia, Latvia, SEM method.

\section{Introduction}

Realizing the great proportion of the minority in percentage in Estonia and Latvia and the necessity of developing tolerance in these multicultural societies the article analyses the link between civic knowledge and skills and the civic attitudes and sense of belonging of Grade 8 students from majority (Estonian, Latvian) schools and minority (Russian) schools. The aim of the research is to establish the model of students' civic competence and to find out factors that explain the influence of civic achievement on civic attitudes. Being able to understand the mutual link of the components forming the citizenship - knowledge, skills and attitudes, the authors hope to find explanation to the role of civic knowledge when developing students' civic attitudes and sense of belonging.

\section{The Ethnic Structure of Estonia and Latvia}

The population census performed in the 30 s of the $20^{\text {th }}$ century testifies that the ethnic structure in Estonia during the period between the wars was slightly more homogeneous than in Latvia. The ethnic Estonians in Estonia were close to ninety per cent $(88 \%)$ of all population but in Latvia the basic nation- Latvians was considerably less - only $77 \%$. The largest minority in both countries was the ethnic Russians - 8.2 \% in Estonia, 8.8 \% in Latvia (Statistics Estonia, 2011; Statistics Latvia, 2011).

The number of population speaking Slavic increased considerably in the occupied Latvia 
Andrejs GESKE, Ireta CEKSE. The Influence of Civic and Citizenship Education Achievements on the Development of Students' Citizenship Attitudes

PROBLEMS

OF EDUCATION

IN THE $21^{\text {st }}$ CENTURY

Volume 52, 2013

and Estonia (Taageoera, 1993) as a result of the immigration wave organized after the Second World War by the elite of the Soviet Union (Vihalemm, Kalmus, 2008). In 1989 shortly before the restoration of independence in comparison with the interwar period the number of ethnic Estonians in Estonia had decreased to $62 \%$ but the number of population of basic nation in Latvia even to $52 \%$. The Russian ethnic group in Estonia had increased to $30 \%$ and in Latvia to $34 \%$ in the same period. The number of other Russian speaking Slavic minorities - Belorussians and Ukrainians had increased considerably, $1.8 \%$ and 3.08\% respectively in Estonia and 4.5\% and 3.5\% in Latvia (Statistics Estonia, 2011; Statistics Latvia, 2011).

\section{Estonia and Latvia in International Democracy and Economy Assessments}

Reports, which compare countries of a particular region or the countries of the world in a definite time period, are regularly published. The place of Estonia and Latvia in the international assessments of different spheres will allow evaluating more objectively the situation in both the countries and answer the research question put forward in the article.

International assessments that indicate the place of Estonia and Latvia in democracy, economy and social sphere are analysed in the article. The data of the latest available international assessments and data collected in 2009 when data were collected for the research used in the article were chosen for the comparison. If any of the democracy assessment studies was not performed in 2009 the time-wise closest study was chosen.

Estonia and Latvia in the ranking of Index of Democracy (Index of Democracy 2008, 2010, 2012) according to data of 2011 study are in the group of countries with incomplete democracy regime, where Estonia compared with Latvia takes a higher place and is closer to the group of explicit democratic countries. Estonia from $37^{\text {th }}$ place $(2007,7.68$ points) has stepped higher to $34^{\text {th }}$ place $(2010,7.61$ points) and has achieved the same result in 2011. Latvia, in its turn, has stepped back since 2007 from $45^{\text {th }}$ place to $48^{\text {th }}$ place in 2011 . It should be mentioned that Latvia takes the last place among all the democratic countries of the Baltic Sea region, lagging behind also Lithuania and Poland, which is forestalled by Estonia.

Like in Index of Democracy, also in Human Development Index Estonia is ahead of Latvia. Estonia has stepped higher from $40^{\text {th }}$ place to $34^{\text {th }}$ place, Latvia from $48^{\text {th }}$ place to $43^{\text {rd }}$ place during the period from 2007 till 2011. In the Human Development Index in 2009 Latvia fell behind Estonia by 14 places (Human Development Index, 2011, 2010, 2009)

The corruption level in the state public sector according to the data of Corruption Perceptions Index in Latvia has increased in the period from 2007 till 2011, thus Latvia has slid down by ten places $\left(51^{\text {st }}\right.$ place in $2007,61^{\text {st }}$ place -2011$)$. The corruption level in Estonia, in its turn, in the state sector is of less occurrence than in Latvia and has not changed much in these years, remaining between $26^{\text {th }}$ and $29^{\text {th }}$ place. (Corruption Perceptions Index 2011, 2010, 2009, 2007)

The annual GDP (PPP) increase regaining independence in 1991 was negative both for Estonia (-9.56\%) and Latvia (-12.6\%). In 2007 when Latvia had already completed but Estonia started the minority school reform Europe experienced a rapid economic rise. The growth of Latvia's GDP exceeded the growth of Estonia's GDP (9.98\% and 7.49\% respectively), which can be explained with the "bubble" of the real estate and spread of grey (shadow) economy. GDP in both countries experienced fall in 2009 (in Estonia-14.07\%, in Latvia-17.95\%), which can be connected with the local and global financial and economic crisis. (World Bank national accounts data, Gross Domestic Product (GDP) of Estonia, 1990-2011) Estonia was less touched by crisis during this time than Latvia, which was forced to borrow from the International Monetary Fund and make unpopular decisions, including the lowering of remuneration in the state sector that influenced people's wellbeing and mood. 
In recent years civic and citizenship education and the citizen's character has been the subject of great international attention, including national and large-scale international surveys. The International Association for the Evaluation of Educational Achievement (IEA) operates since 1958 performing large-scale international surveys. IEA organized its first cycle in 1971 where civic and citizenship education was also included in the survey of six subjects among the science, reading literacy, literature, English and French as a foreign language. The justification for including civic and citizenship education in the survey was the view that knowledge and skills in the field of civic and citizenship education are as important as knowledge and skills in mathematics and foreign languages. (Schulz, Frallion, Ainley, Losito \& Kerr, 2008).

The second cycle of civic and citizenship education study was organized in 1999, and the third in 2009. The aim of the ICCS 2009 study was to explore to which extent the young people of the participating countries are ready to undertake different civic role. In order to achieve it, students' conceptual understanding, knowledge and skills in civic and citizenship education were explored.

Estonia and Latvia have participated in the two last cycles.

\section{Elements Forming the Civic Competence}

The concept of civic competence and civic and citizenship education has become topical in the last decades, which is described as the social dimension and is connected with the inclusion of the individual and/or isolation from the society (Horsdal, 2001) promoting or hindering the understanding about the development of diversity, the acceptance of the individual's human features and action.

An important objective of civic and citizenship education is focusing on the development of individual skills facilitating favourable exchange of intercultural experience (Kymlicka, 2003), forming the identity of the society, sense of belonging, historic memory, increasing the feeling of patriotism and loyalty to country in which the individual lives.

Characterizing the civic concept the authors point out civic skills (Weissberg, 2001; Bernstein, 2007), describe indirectly the role of knowledge (Cogan, 1998; Andersone 2008) that form the individual's attitudes.

Some elements of the concept of the citizen are included in the structure model of civic and citizenship education, which O. Korsgaad (Korsgaad, 2001) explains synthesizing the classical taxonomy terminology model and pointing out three elements: knowledge and understanding, values and dilemmas and skills.

O. Korsgaad explains knowledge in civic and citizenship education as an element without which citizenship cannot exist. He grounds his statement indicating that knowledge in the context of civic and citizenship education determines continuous learning about rights and responsibilities, civic society, market economy, citizenship and democracy concepts, theories about nation and people (as demos, ethnos, class), diversity (concept of multiculturalism), citizenship as status and sense of belonging. Other authors, too, emphasize the role of knowledge in civic and citizenship education (e.g., Banks, 1997; Mitscke \& Szumska, 2008; Torney-Purta, 2002; Rathenow \& Weber, 1995).

O. Korsgaad, describing values and dilemmas, includes individual and collective emotional dimension of the citizenship giving examples that are connected with moral principles and moral dilemmas: freedom, equality, solidarity, responsibility, rights, justice, regulations, laws, tolerance, identity, ethnicity, religion, gender. (Korsgaad, 2001) Other authors (Nye, 2007; Kymlicka, 2007; Kymlicka, 2003; Kymlicka, 2002; Cogan, 1998; Hoskins, 2006; Jarvis, 2001; Horsdal, 2001), describing the above mentioned terms mention civic attitudes that have different forms and expressions, but $\mathrm{H}$. Biseth (Biseth, 2009) defines the importance of values and attitudes as one of the components of the content of civic and citizenship education. 
Andrejs GESKE, Ireta CEKSE. The Influence of Civic and Citizenship Education Achievements on the Development of Students' Citizenship Attitudes

EMS

OF EDUCATION

IN THE $21^{\text {st }}$ CENTURY

Volume 52, 2013

O. Korsgaad like other authors (Cogan, 1998; Weissberg, 2001, Bernstein, 2007) defines civic skills as the individual's ability to communicate, to form a dialogue, to live together with others, to solve conflicts in a non-violent way, to interact, to participate in public debates, to identify and accept differences, to use information and information technologies. Examples that can be linked with the skill in the context of civic and citizenship education are critical thinking, participation, decision making, analysis, and argumentation, disciplined and constructive debates.

\section{Methodology of Research}

\section{Data Processing}

In the research uses the latest available international comparative data concerning Estonia and Latvia from the International Civic and Citizenship Study 2009 (ICCS 2009). Next international civic and citizenship education study will be in 2016 (ICCS 2016).

2743 Grade 8 students participated in the study in Estonia, of whom 2177 students from Estonian speaking schools, 566 students from Russian speaking schools. The sample of Latvia included 2602 Grade 8 students, of whom 1992 were students from Latvian speaking schools, 610 students from Russian speaking schools.

Analysis of the dominant language which students speak at home allowed finding out that less than $10 \%$ in each group speak language that differs from the instruction language at school. Taking into account the small number of representatives of other ethnic groups it is assumed for the purposes of the article that students from schools with the same language of instruction represent one ethnic group. Hereafter in the text, the authors will indicate students' national belonging, for example, Estonian students speaking the state language, Latvian students speaking the Russian language, etc.

Data are taken from students' questionnaire, test and the questionnaire part of the European module. Students' civic knowledge and skills were identified with the help of the test, the civic attitudes, in their turn, were measured with the help of questionnaires (students' questionnaire and European module). The questions in the questionnaire were formulated on the four point Likert scale and answers were coded according to data logics.

Students according to the test results were grouped in four levels of civic knowledge and skills. Students with the highest number of points in the test corresponded to Level 3; students who had the lowest number of points in the test were equalled to Level 1 but students who did not reach Level 1 were defined as "below Level 1".

\section{Statistical Methods}

The method of descriptive statistics and Structural Equation Modelling (SEM) were used in the research. SEM is a method that combines analysis of regressions and factor analysis. SEM method allows exploring relations (connections and influence) between the manifesting and latent variables. (Everitt, 2002)

The SEM model was worked out considering several steps (Hair, Tatham, Anderson \& Black; 1998; Zaksa, 2012). Firstly, the latent and manifesting variables were defined, which were used to measure the construct. The measurement model was developed in the second step showing the mutual relations of indicators and variables. The goodness of fit of the sample's scope was assessed in the third step; the chosen assessment methods and the goodness of fit of the method processing the missing data were evaluated in the fourth and fifth steps. The structural model was worked out in the sixth step and, taking into account the indicators of the suitability of the model, the goodness of fit of the measurement model was assessed in the seventh step. 
Andrejs GESKE, Ireta CEKSE. The Influence of Civic and Citizenship Education Achievements on the Development of Students' Citizenship Attitudes

Indicators Determining the Suitability of the Model

\begin{tabular}{l} 
PROBLEMS \\
OF EDUCATION \\
IN THE 21 $1^{\text {st }}$ CENTURY \\
Volume 52, 2013 \\
\hline 25
\end{tabular}

Several indicators were used to determine the suitability of the model (Schreiber, 2008).

Relations of the Chi square $\left(\chi^{2}\right)$ and number of degrees of freedom that explain the absolute fit indices. It is advised using the SEM model to identify these indices because when modelling they form several fit indices.

RMSEA (The Root Mean Square Error of Approximation), absolute credibility indicator, which indicates whether the developed model is valid. RMSEA is considered optimal if it is less or equals .06 but is no lower than 0.02 . Analysing RMSEA index for small samples it is necessary to take into account the sample error. Indices that are also used for measuring the suitability of the model - SRMR (Standardized Root Mean Square Residual) and GFI (Goodness-of-Fit Index).

Similarly the Incremental suitability index CFI (Comparative Fit Index) is used, which helps to check how well the collected data fit the measurement model and whether the model is valid (Goodness-of-Fit Index). Optimal CFI is $\geq 0.95$. The similar indices that are measured to identify the suitability are GFI and TLI (Tucker-Lewis Index).

In order to analyse comparatively the connection of civic knowledge and skills of all four sample groups with the civic attitudes SEM multi-model was used. Statistical data processing program SPSS and program of structural equation modelling AMOS was used for data processing.

\section{Latent Variables of the Model Measuring the Multicultural Civic Competence}

The development of SEM model is based on the elements of the civic competence worked out in the theoretical part- civic attitude, sense of belonging, knowledge and skills. The latent variables - five scales of attitude and sense of belonging are developed from questions included in students' questionnaire and European module (see Table1). The latent variable of students' civic knowledge and skills is developed from (PV1CIV, PV2CIV, PV3CIV, PV4CIV, PV5CIV), which were obtained from the results of students' test. 
Andrejs GESKE, Ireta CEKSE. The Influence of Civic and Citizenship Education Achievements on the Development of Students' Citizenship Attitudes

PROBLEMS

OF EDUCATION

IN THE $21^{\text {st }}$ CENTURY

Volume 52,2013

Table 1. Variables describing the civic attitude and sense of belonging, knowledge and skills.

\begin{tabular}{|c|c|c|}
\hline Latent variables & $\begin{array}{l}\text { Manifesting variables (questions from the questionnaire included } \\
\text { in the scale) }\end{array}$ & Remarks \\
\hline $\begin{array}{l}\text { Importance of } \\
\text { language acquisi- } \\
\text { tion }\end{array}$ & $\begin{array}{l}\text { - Learning a foreign European language is important for travelling/ } \\
\text { going on holidays in Europe } \\
\text { - Learning foreign European languages can make it easier to find } \\
\text { a job. } \\
\text { - Learning a foreign European language is important for working or } \\
\text { studying in another European country. } \\
\text { - Learning a foreign European language helps people understand } \\
\text { other European cultures better. } \\
\text { - Schools should give young people more opportunity to learn } \\
\text { foreign languages used in other European countries. }\end{array}$ & $\begin{array}{l}\text { Part of the question- } \\
\text { naire of the European } \\
\text { module }\end{array}$ \\
\hline $\begin{array}{l}\text { Equality of citi- } \\
\text { zens of European } \\
\text { countries }\end{array}$ & $\begin{array}{l}\text { Citizens of European countries who come to Estonia/Latvia should } \\
\text { have the same opportunities as people from Estonia/Latvia. } \\
\text { - } \quad \text { whatever their ethnic or racial background. } \\
\text { - Whatever their religion or beliefs. } \\
\text { - Whatever language they speak. } \\
\text { - Whether they come from a rich country or a poor one. }\end{array}$ & $\begin{array}{l}\text { Part of the question- } \\
\text { naire of the European } \\
\text { module }\end{array}$ \\
\hline Ethnic diversity & $\begin{array}{l}\text { - All ethnic/racial group should have an equal chance to get a good } \\
\text { education in Estonia/Latvia } \\
\text { - All ethnic/racial groups should have an equal chance to get good } \\
\text { jobs in Estonia/Latvia } \\
\text { - Schools should teach students to respect embers of all ethnic/ } \\
\text { racial groups } \\
\text { - Members of all ethnic/racial groups should be encouraged to run } \\
\text { in elections for political office } \\
\text { - Members of all ethnic/racial groups should have the same rights } \\
\text { and responsibilities }\end{array}$ & $\begin{array}{l}\text { Students' question- } \\
\text { naire, Citizen and } \\
\text { society question group }\end{array}$ \\
\hline Civil rights & $\begin{array}{l}\text { - } \\
\text { freryone should always have the right to express their opinions } \\
\text { - } \quad \text { Political leaders should not be allowed to give government jobs to } \\
\text { their family members } \\
\text { - } \quad \text { No company or government should be allowed to own all news- } \\
\text { papers in a country } \\
\text { - All people should have their social and political rights respected } \\
\text { - All citizens should have the right to elect their leaders freely }\end{array}$ & $\begin{array}{l}\text { Students' question- } \\
\text { naire, Citizen and } \\
\text { society question group }\end{array}$ \\
\hline $\begin{array}{l}\text { Sense of belong- } \\
\text { ing to Europe }\end{array}$ & $\begin{array}{l}\text { - I see myself as European. } \\
\text { - I am proud to live in Europe. } \\
\text { I see myself first as a citizen of Europe and then as a citizen of } \\
\text { the world. } \\
\text { - I feel part of the European Union. }\end{array}$ & $\begin{array}{l}\text { Part of the question- } \\
\text { naire of the European } \\
\text { module }\end{array}$ \\
\hline $\begin{array}{l}\text { Civic knowledge } \\
\text { and skills }\end{array}$ & $\begin{array}{l}\text { The questions included in Students' test are used in setting up the } \\
\text { scale. }\end{array}$ & Students' test \\
\hline
\end{tabular}

Cronbach alfa internal correlation ratio $(\alpha)$ was defined for five variables describing attitudes and belonging. The results showed that of $\alpha$ latent variables was in the boundaries from 0.70 to 0.93 , which was considered an optimal result. The results showed that latent variables $\alpha$ was in the boundaries. 
Andrejs GESKE, Ireta CEKSE. The Influence of Civic and Citizenship Education Achievements on the Development of Students' Citizenship Attitudes

\section{Results of Research}

The Model of Multicultural Civic Competence

Multicultural civic competence model was developed from six latent variables of which one characterizes students' civic knowledge and skills, four variables - students' civic attitudes and one variable - students' sense of belonging. Latent and manifesting variables that form latent variables are presented in Table 1. The variable "Students' civic knowledge and skills" in the model is the exogenous variable and the others are endogenous variables.

The model analysis was performed both for Estonian and Latvian data together and separately for each country, making a possibility to compare mutually the model indices in the structural model.

The developed measurement model $\chi^{2}=3771.26$ and $\mathrm{df}=345, \chi^{2} / \mathrm{df}=10.93$, RMSEA $=0.043$, $\mathrm{CFI}=0.96$ and the established conceptual model $\chi^{2}=3771$ and $\mathrm{df}=345, \chi^{2} / \mathrm{df}=10, \mathrm{RMSEA}=0.043$, $\mathrm{CFI}=0.96$. There is no difference between the validity index of the conceptual model and measurement model RMSEA and CFI, the number of free power differs by 0.54 units. Differences of the CFI suitability index will not influence the common result. On the whole the indices of the conceptual model correspond to the generally accepted norms and differences from the measurement model are acceptable.

Using the SEM method it is important to determine the scope of missing data and to process them. B. Byrne (Byrne, 2001) points out that the shortage of data cannot exceed 25\%. In this research, analysing the established latent variables, the proportion was within boundaries from $0.6 \%$ to $1.1 \%$. The missing data were transformed using SPSS function, which is envisaged for data processing before the data analysis in the chosen model.

A simplified conceptual model of civic competence is presented in Figure 1, which shows the influence of the exogenous variable Civic knowledge and skills on the endogenous variables- Equality of European citizens, Sense of belonging to Europe, Importance of language acquisition, Ethnic diversity and Citizens' rights.

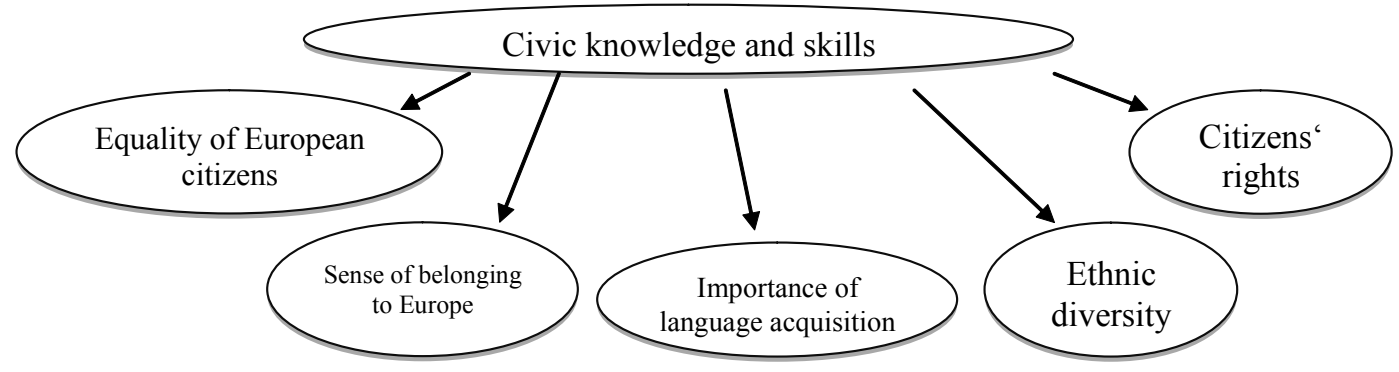

Figure 1: Simplified conceptual model of civic competence of the multicultural model.

Students' Achievement in the Test

The level of students' knowledge and skills in four sample groups - Estonian students from Estonian speaking and Russian speaking schools, Latvian students from Latvian speaking and Russian speaking schools were compared.

Estonian students from Estonian speaking schools showed the highest civic knowledge and skills. The civic knowledge and skills of 39\% of this students' sample corresponded to Level $3.34 \%$ - level 2, the civic knowledge and skills of the remaining $27 \%$ corresponded to the 
Andrejs GESKE, Ireta CEKSE. The Influence of Civic and Citizenship Education Achievements on the Development of Students' Citizenship Attitudes

OF EDUCATI

IN THE $21^{\text {st }}$ CENTURY Volume 52, 2013

lowest levels. Comparing students among the sample groups, Latvian students from Russian speaking schools had the lowest level of knowledge and skills - only 14\% had reached Level 3.33\% - Level 2, most students were in Level 1 and below Level 1 (36\% and17\% respectively). Students from Estonian minority schools and Latvian minority schools had a similar division of levels. More than a half of students were on Levels 3 and 2, 18\% and 36\% respectively, and Latvian students from Latvian speaking schools $21 \%$ and $34 \%$ of Estonian students from Russian speaking schools. $33 \%$ and $14 \%$ of Latvian students from Latvian speaking schools, respectively, and $36 \%$ and $17 \%$ of Estonian students from Russian speaking schools are in Level 1 and below level 1.

\section{Differences of Civic Attitudes of Estonian and Latvian Students Depending on Students ' Achievement in the Test}

In order to find out whether students' attitude and sense of belonging change depending on their knowledge and skills, scales were made using the questions selected for the model. The mean value of the scale was 50 and standard error 10. Results shown in Table 2 indicate that students' civic attitude and sense of belonging change depending on students' level of knowledge and skills. Results show that those students of Estonia and Latvia whose level of civic and citizenship education in ICCS 2009 test corresponded to Level 3 were more positive and more open to democratic values; besides they also had a more pronounced sense of belonging to Europe. Students, whose knowledge and skills corresponded to the lowest level, in their turn, had a more negative attitude. The obtained results are statistically significant with $95 \%$ credibility level.

Table 2. Scale value differences of Estonian and Latvian students' attitude depending on students' achievement in the test ( $M$ 50, SE 10).

\begin{tabular}{lccccccccc}
\hline & \multicolumn{4}{c}{ Estonia } \\
\cline { 2 - 8 } Scale (latent variable) & \multicolumn{3}{c}{ Below Level 1 M (SE) } & $\begin{array}{c}\text { Level 3 } \\
\text { M (SE) }\end{array}$ & Below Level 1 M (SE) & $\begin{array}{c}\text { Level 3 } \\
\text { M (SE) }\end{array}$ \\
\cline { 2 - 9 } & 48 & $(0.90)$ & 51 & $(0.27)$ & 47 & $(0.56)$ & 52 & $(0.68)$ \\
Importance of language acquisition & 49 & $(1.36)$ & 53 & $(0.35)$ & 48 & $(0.74)$ & 50 & $(0.51)$ \\
Equality of European citizens & 50 & $(0.75)$ & 53 & $(0.40)$ & 47 & $(0.83)$ & 49 & $(0.39)$ \\
Sense of belonging to Europe & 50 & $(1.76)$ & 54 & $(0.32)$ & 47 & $(0.56)$ & 50 & $(0.37)$ \\
Ethnic diversity & 47 & $(1.13)$ & 51 & $(0.27)$ & 46 & $(0.70)$ & 53 & $(0.34)$ \\
Citizens' rights & & & & & & & & & \\
\hline
\end{tabular}

\section{Structural Multi-model of Students'Multicultural Civic Competence}

According to the theory of developing a multi-group model (Byrne, 2001) the multimodel was developed. The number of $\chi^{2}$ and free powers $(\mathrm{df})(\mathrm{p}<0.005)$ has increased in the structural model in comparison with the measurement model. In the measurement model $\chi^{2}=4527$, but in the structural model the ratio has increased by 975 . The number of free powers of the structural model has increased by 12 . The other changes of the goodness of fit indices are insignificant- suitability index of the model CFI has changed by 0.001 and credibility index RMSEA - 0.003. $\chi^{2}$ considerable changes can be explained by the non-homogeneity of the sam- 
Andrejs GESKE, Ireta CEKSE. The Influence of Civic and Citizenship Education Achievements on the Development of Students' Citizenship Attitudes

ple groups, which is determined by numerically small groups - Estonian students from Russian PROBLEMS OF EDUCATION IN THE $21^{\text {st }}$ CENTURY Volume 52, 2013 speaking schools and Latvian students from Russian speaking schools.

Comparing the results among the groups, it is seen that civic knowledge and skills influence the civic attitude and sense of belonging the most in case of Estonian students from Estonian speaking schools and Latvian students from Latvian speaking schools (Table 3).

Table 3. Standardized regression ratios of mutual relations of latent variables of the structural model of students' multicultural civic competence (according to language of instruction).

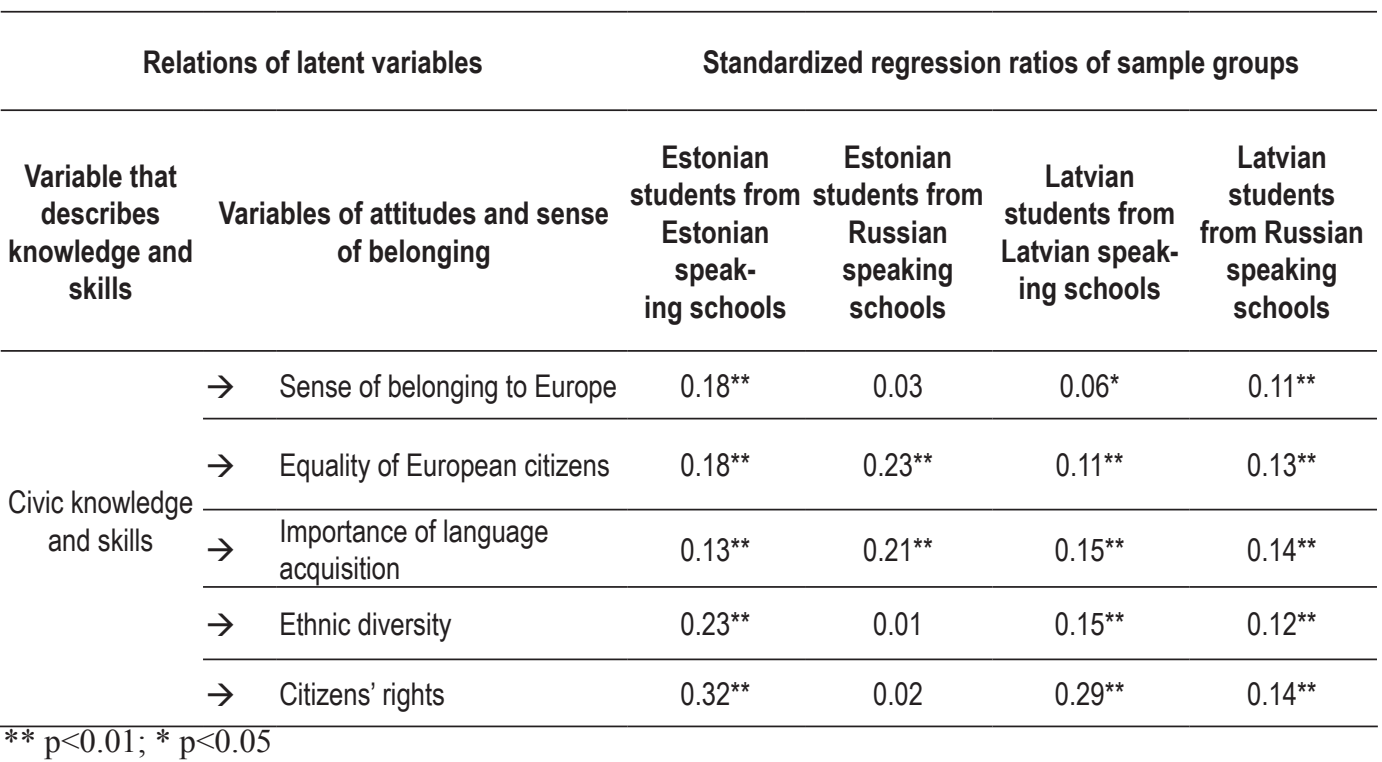

Estonian students from Russian speaking schools in comparison with students from other sample groups have a higher influence of civic knowledge and skills on the attitude to the importance of language acquisition $(\beta=0.21 ; \mathrm{p}<0.01)$. Knowledge and skills influence the least the attitude to language acquisition Estonian students with the state language and Latvian students from Russian speaking schools $(\beta=0.13 ; \beta=0.11$ respectively; both $p<0.01)$. Civic knowledge and skills have an essential influence on forming the attitude to the equality of European citizens for Estonian students from Russian speaking schools in comparison with the results of other groups. Knowledge and skills equally strongly influence the equality of European citizens $(\beta=0.18 ; p<0.01)$ and the sense of belonging to Europe $(\beta=0.18 ; p<0.01)$ in case of Estonian students from Estonian speaking schools.

Comparing students who learn in Russian and Latvian languages, knowledge and skills influence the most the attitude of Estonian students from Estonian speaking schools to ethnic diversity and citizens' rights, the regression ratio is $\beta=0.23$ and $\beta=0.32$ respectively, $p<0.01$. For Estonian students from Russian speaking schools the above mentioned influence is not statistically significant; the knowledge and skills of these students do not influence the sense of belonging to Europe. The influence of knowledge and skills on the sense of belonging to Europe is low for Latvian students from Latvian speaking schools. 
Andrejs GESKE, Ireta CEKSE. The Influence of Civic and Citizenship Education Achievements on the Development of Students' Citizenship Attitudes

\section{PROBLEMS \\ OF EDUCATION \\ IN THE $21^{\text {st }}$ CENTURY \\ Volume 52,2013 \\ 30 \\ Discussion}

The present analysis allows making several important conclusions concerning the connection between students' civic knowledge and civic attitudes and sense of belonging. Several authors (Andersone 2008; Kymlicka, 2003; Korsgaad, 2001; Cogan, 1998; Weissberg, 2001; Bernstein, 2007) emphasize that the skills, knowledge and attitudes are important for students' civic and citizenship education.

Firstly, the civic attitudes of Estonian and Latvian students are influenced by the level of civic knowledge and skills. Students with higher level of civic knowledge and skills have a more pronounced sense of global belonging, the ability to adjust and live in a multicultural society. Estonian students in ICCS 2009 civic knowledge and skills test on the whole have higher achievement than Latvian students (Schulz, Ainley \& Fraillon, 2011; Schulz, Ainley, Fraillon, Kerr \& Losito, 2010). A. Toots and T. Idnurm (Toots \& Idnurm, 2012) explain the achievement of Estonian and Latvian students in ICCS 2009 test with the differences of teaching civic and citizenship education in school, indicating that in Estonia the content of civic and citizenship education is integrated in several subjects while in Latvia civic and citizenship education is acquired in social science subject. Statistically significant difference between attitudes and knowledge are stated also in other IEA international comparative studies. For instance, the mentioned correlation is found in The Progress in International Reading Literacy Study - PIRLS (Thompson, et all., 2012) un Trends in International Mathematics and Science Study - TIMSS (Mullis, Martin, Arora, 2012).

The authors of the article consider that the civic attitudes of Estonian and Latvian students are significantly influenced by the state environment, i.e., the influence of economic and social factors on the students' stand and opinion about civic issues. We have to remember that in international assessments of democracy and economic situation Estonia is ahead of Latvia (Human Development Index, 2011, 2010, 2009; Index of Democracy 2008, 2010, 2012; Corruption Perceptions Index 2011, 2010, 2009, 2007). Estonia in comparison with Latvia is recognized as more democratic, less corrupted and its GDP is higher (World Bank national accounts data, Gross Domestic Product (GDP) of Estonia, 1990-2011).

Secondly, the obtained results point out explicit differences among students who learn in the state language and Russian. Students, who learn in the state language, have the highest relation of knowledge and skills with the attitude to citizens' rights in the broadest sense. This influence is less pronounced for Latvian students from Russian speaking schools but Estonian students from Russian speaking schools do not have this influence at all. There are several possible reasons for the weak link between knowledge and attitude to citizens' rights of the Estonian and Latvian students from Russian speaking schools (Banks, 1997). The authors consider that the unclear legal status, which is intensified by the weal legislation environment regarding non-citizens in Estonia and Latvia, is the reason why students from Russian speaking schools and their relatives have a weak sense of belonging and they do not identify themselves as belonging to the civic society of the concrete country. This results in the next conclusion that these minority school students understand the concept of citizenship only in the narrow sense, connecting it only with the legal aspect and consciously or unconsciously do not define themselves as belonging to the concrete civil society. Some authors (Golubeva, 2010) indicate that the learning content in majority and minority schools differs interpreting the past and future aspects of the civil society can serve as a reason for the formation of a split society.

However, despite the lack of understanding of the wholeness of citizens' rights, students from Russian speaking schools show the connection of knowledge and skills with some elements of citizens' rights (Korsgaad, 2001; Torney-Purta, 2002). Russian ethnic minority students in comparison with students from state language schools have a more positive attitude and understanding on equality issues and the role of language acquisition, which influence them as belonging to the citizens of the European Union, the freedom of movement, possibilities of studies in future and career possibilities outside the country. 
Thirdly, the comparison with students of other sample groups shows that civic knowledge and skills of Estonian students from Estonian speaking schools influence the civic attitude and sense of belonging to Europe most essentially. It should be admitted once more that Estonian students from state language schools had the highest achievement in ICCS 2009 test (Schulz, Ainley \& Fraillon, 2011). Latvian students from Russian speaking schools, in their turn, who had the lowest achievement in ICCS 2009 test, the influence of knowledge and skills on civic attitudes as the weakest. The research results indicate the essential role of civic knowledge in the process of developing civic attitudes and the sense of belonging. Other research results also show that representatives of Russian ethnic groups have a lower sense of belonging (Korol̦eva, Sniķere, Trapenciere, Trapencieris, 2005), which can be explained that they have a greater sense of belonging to their ethnic or home country and weak knowledge about the civic processes.

The research authors have not examined other factors that could have a link with the formation of civic attitudes. Taking into consideration that citizenship and civic issues are defined as interdisciplinary the authors suggest continuing the research aiming at and focusing on the influence of parents, school, teachers and society factors on the formation of students' civic attitudes. The extended research of relations between the civic attitude and the above mentioned factors will provide a more complete explanation on what influences the formation of students' civic attitudes and what link the level civic knowledge and skills have with them.

\section{Conclusions}

Taking ICCS 2009 study data as the basis, it was proved that civic attitudes of Estonian and Latvian students are connected with the level of civic knowledge and skills. Students who have a higher level of civic knowledge and skills have a more explicit sense of global belonging, the ability to adjust and live in a multicultural society. It was found out that Estonian students from Estonian speaking schools had the highest level of civic knowledge and skills, Latvian students from Russian speaking schools had the lowest level. Latvian students from Latvian speaking schools and Estonian students from Russian speaking schools had a comparatively similar level of civic knowledge and skills.

The research points out the differences of students' attitudes depending on the language of instruction. The research findings indicate that in case of Estonian students from Estonian speaking schools civic knowledge and skills influence the civic attitude and sense of belonging to Europe. However, Latvian students from Russian speaking schools have the weakest connection between knowledge and skills and civic attitudes.

The obtained results serve as evidence for the link between the civic knowledge and the formation of students' civic attitudes in the process of civic and citizenship education. This connectedness should be taken into account in organizing the teaching/learning process in school, teacher education and the development of education and civic and citizenship education policy thus ensuring the holistic approach in developing civic and citizenship education for schoolaged young people.

\section{Acknowledgements}

This work has been supported by the European Social Fund within the project 'Support for Doctoral Studies at University of Latvia' and State research program "National identity".

\section{References}

Andersone, R. (2008). Sociālās prasmes izglītības programmās. Sabiedrība. Integrācija. Izglìtība. 335 341.

Banks, J. A. (1997). Educating Citizens in a Multicultural Society. New York: Teachers College Press. 
Andrejs GESKE, Ireta CEKSE. The Influence of Civic and Citizenship Education Achievements on the Development of Students' Citizenship Attitudes

PROBLEMS

OF EDUCATION

IN THE $21^{\text {st }}$ CENTURY Volume 52,2013

Bernstein, J. L. (2007). Simulations and the Dynamics of Racial and Gender Gaps in Civic Competence. New Directions for Teaching \& Learning, 111, 89-96.

Biseth, H. (2009). Democracy and Education in a Multicultural Scandinavia: What Mandate is Designated to Educators? Intercultural Education, 20 (3), 243-254.

Byrne, B. M. (2001). Structural equation modeling with AMOS: basic concepts, applications, and programming. Mahwan, London: Lawrence Erlbaum Associates.

Cogan, J. J. (1998). Citizenship for the 21st Century. An International Perspective on Education. In J. J. Cogan, \& R. Derrcott, Citizenship education for the 21st century: Setting the context. (pp. 1-20.). London: Kogan Page.

Everitt, B. S. (2002). The Cambridge dictionary of statistics. UK: Cambridge University Press.

Golubeva, M. (2010). Different History, Different Citizenship? Competing Narratives and Diverging Civil Enculturation in Majority and Minority Schools in Estonia and Latvia. Journal of Baltic Studies, 41 (3), 315-329.

Gross Domestic Product. (n.d.). Retrieved 02/ 01/ 2013, from http://kushnirs.org/macroeconomics/gdp/ gdp estonia.html\#t2 2

Hair, F., Tatham, R., Anderson, R., \& Black, W. (1998). Multivariate Data Analysis. 5th Edition. New Jersey: Prentice Hall.

Horsdal, C. (2001). Affiliation and Participation - Narrative Identity. In O. Korsgaard, S. Walters, \& R. Andersen, Learning for Democratic Citizenship (pp. 123-136.). Copenhagen: Association for World Education at the Danish University of Education.

Hoskins, B. (2006). ICCS European report and European Module. Amsterdam: International Association for the Evaluation of Educational Achievement.

Human Development Report. (2011). Human Development Statistical Tables. Retrieved 23/01/2013, from: http://hdr.undp.org/en/reports/global/hdr2011/download/

Human Development Reports. (2009.). Human Development Report 2009 Overcoming barriers: Human mobility and development. Retrieved 23/01/2013, from Download the Report. HDR 2009 Statistical Tables: http://hdr.undp.org/en/reports/global/hdr2009/

Jarvis, P. (2001). Active Citizenship and Lifelong Learning. O. Korsgaard, S. Walters, \& R. Andersen, Learning for Democratic Citizenship (pp. 82.-96.). Copenhagen: Association for World Education at the Danish University of Education.

Koroḷeva, I., Sniķere, S., Trapenciere, I., \& Trapencieris, M. (2005). Jauniešu identitātes veidošanās un lìdzdalība. Pētījuma pārskats 2005. Rīga: Latvijas Universitātes Filozofijas un socioloǵijas institūts.

Korsgaad, O. (2001). Why Citizenship Become such a Vogue World? In O. Korsgaard, R. Walters, \& R. Andersen, Learning for Democratic Citizenship (pp. 9.-16.). Copenhagen: Association for World Education on the Danish University of Education.

Kymlicka, W. (2002.). Contemporary Political Philosophy. An Introduction. Oxford: Oxford University Press.

Kymlicka, W. (2003). Multicultural States and Intercultural Citizens. Theory and Research in Education, $1,147-169$.

Kymlicka, W. (2007). Multicultural Odysseys: Navigating the New International Politics of Diversity. Oxford: Oxford University Press.

Mitschke, K., \& Szumska, J. (2008). How to Educate Children to be Responsible Citizens? Postulates vs. Reality in Poland. In D. Bluma, I. H. Merici, S. Kiefer, \& C. Papasolomant, ACEP (Analysis of Comparative Education Policies). Texts from the European Intensive Programme ACEP 2007 (pp. 199-207). Linz: State College of Teacher.

Mullis, I.V.S., Martin, M.O., Foy, P., \& Arora, A. (2012). The TIMSS 2011 International Results in Mathematics The TIMSS 2011 International Results in Mathematics. Chestnut Hill, MA: TIMSS \& PIRLS International Study Centre, Boston College.

Nye, M. (2007). The Challenges of Multiculturalism. Culture and Religion, 8 (2), 109-123.

Rathenow, H. F., \& Weber, N. H. (1995). Education for Peace, Justice and Human Rights in the Context of Teacher Training: some methodological reflections. In H. R. A. Osler, Teaching for Citizenship in Europe. (pp. 47. - 54.). Staffordshire: Tentham Book Limited. 
Andrejs GESKE, Ireta CEKSE. The Influence of Civic and Citizenship Education Achievements on the Development of Students' Citizenship Attitudes

Report, H. D. (2010). The Real Wealth of Nations: Pathways to Human Development. Report statistical data. HDR 2010 Statistical Tables. Retrieved 03/01/2013, from: http://hdr.undp.org/en/reports/ global/hdr2010/chapters

Schreiber, J. B. (2008). Core reporting practices in structural equation modeling. Research in Social and Administrative Pharmacy, 4 (2), 83-97.

Schulz, W., Ainley, J., \& Fraillon, J. (2011). ICCS 2009 Technical Report. Amsterdam: International Association for the Evaluation of Educational Achievement.

Schulz, W., Ainley, J., Fraillon, J., Kerr, D., \& Losito, B. (2010). Initial Findings from the IEA International Civic and Citizenship Education Study. Amsterdam: International Association for the Evaluation of Educational Achievement.

Schulz, W., Frallion, J., Ainley, J., \& Losito, B. (2008). International Civic and Citizenship Education Study. Assessment Framework. Amsterdam: International Association for the Evaluation of Educational Achievement.

Statistics Estonia. (2012). Main demographic indicators. Retrieved 13/02/2013, from: http://pub.stat.ee/ px-web.2001/Dialog/statfile1.asp

Statistics Latvia. (2012). Main demographic indicators. Retrieved 13/02/2013, from: http://www.csb. gov.lv/en

Taagepera, R. (1993). Estonia: Return to Independence. Boulder, San Francisco, Oxford: Westview.

Transparency International. (2010). Corruption Perceptions Index 2010. Retrieved 23/01/2013, from: http://www.transparency.org/cpi2010/results

The Economist. (2008). Economist Intelligence Unit. The Economist Intelligence Unit's Index of Democracy 2008. Retrieved 13/02/2013, from: http:/graphics.eiu.com/PDF/Democracy\%20 Index\%202008.pdf

The Economist. (2010). Democracy index 2010. Democracy in retreat. A reporting from The Economist Intelligence Unit. Retrieved 13/02/2013, from http://graphics.eiu.com/PDF/Democracy_ Index_2010_web.pdf

The Economist. (2011). Democracy index 2011. Democracy under stress. A reporting from The Economist Intelligence Unit. Retrieved 13/02/2013, from: http:/www.sida.se/Global/About\%20Sida/ S\%C3\%A5\%20arbetar\%20vi/EIU_Democracy_Index_Dec2011.pdf

Toots, A., \& Idnurm, T. (2012). Does the Context Matter? Attitudes Towards Cosmopolitanism Among Russian-Speaking Students in Estonia, Latvia and the Russian Federation. Journal of Baltic Studies, 43 (1), 117-134.

Torney-Purta, J. (2001). The School's Role in Developing Civic Engagement: A Study of Adolescents in Twenty-Eight Countries. Applied Developmental Science, 6 (4), 203-212.

Thompson, S., Provasnik, S., Kastberg, D., Ferraro, D., Lemanski, N., Roey, S., \& Jenkins, F. (2012). Highlights from PIRLS 2011: Reading achievement of U.S. fourth grade students in an international. Retrieved 13/02/2013, from: http://nces.ed.gov/pubs2013/2013010.pdf

Transparency International. (2007). Surveys and indices 2007 Corruption Perceptions Index. Retrieved 13/02/2013, from: http://archive.transparency.org/policy_research/surveys_indices/cpi/2007

Transparency International. (2009). Corruption Perceptions Index 2009. Retrieved 13/02/2013, from: http://archive.transparency.org/policy research/surveys indices/cpi/2009/cpi 2009 table

Transparency International. (2011). Corruption Perceptions Index 2011. Retrieved 13/02/2013, from: http://www.transparency.org/cpi2011/results

Vihalemm, T., \& Kalmus, V. (2008). Mental Structures in Transition Culture: Differentiating Patterns of Identities and Values in Estonia. East European Politics and Societies, 2 (4), 901-927.

Weissberg, R. (2001). Democratic Political Competence: Clearing the Underbrush and a Controversial Proposal. Political Behaviour, 23 (3), 257-284.

World data bank. (n.d.). World Bank national accounts data, OECD National Accounts data files. Retrieved 03/01/2013, from http://databank.worldbank.org

Zaksa, K., (2012). The Student Loyalty Management in Higher Education Organizations in Latvia. Doctor's Degree. Riga, University of Latvia. 
Andrejs GESKE, Ireta CEKSE. The Influence of Civic and Citizenship Education Achievements on the Development of Students' Citizenship Attitudes

PROBLEMS

OF EDUCATION

IN THE $21^{\text {st }}$ CENTURY

Volume 52, 2013

Received: January 25, 2013

Accepted: March 14, 2013

Andrejs Geske $\quad$ Dr.oec., Professor, Head of Institute of Education Research, Faculty of Education, Psychology and Art, University of Latvia, Jurmalas Street 74/78, Riga LV-1083, Latvia.

E-mail: andrejs.geske@lu.lv

Website: http://www.lu.Iv/par/kontaktinformacija/meklesana/persona/32478/

Ireta Cekse

Mag.edu.sec., PhD Student of Education Management, Faculty of Education, Psychology

and Art, University of Latvia, Jurmalas Street 74/78, Riga LV-1083, Latvia.

E-mail: ireta.cekse@lu.Iv

Website: http://www.lu.Iv/par/kontaktinformacija/meklesana/persona/175392/ 